Arch. Tierz., Dummerstorf 51 (2008) 4, 338-350

Department of Animal Nutrition and Management, Swedish University of Agricultural Sciences, Uppsala, Sweden

MAGDALENA HØØK PRESTO, H. KRISTINA ANDERSSON, SOFIA FOLESTAM and JAN ERIK LINDBERG

\title{
Activity behaviour and social interactions of pigs raised outdoors and indoors
}

\begin{abstract}
Activity behaviour and social interactions of pigs in indoor and outdoor systems fed different levels of amino acids were studied on 96 crossbred pigs (Hampshire $\times$ Swedish Landrace $\times$ Swedish Yorkshire). The pigs were born outdoors and raised indoors in conventional pens or outdoors on pastures and given recommended $(\mathrm{R}), 7 \%$ lower (R-7) or $14 \%$ lower (R-14) levels of amino acids, in a phase feeding system with a low-energy diet provided ad libitum. Pigs in the outdoor system walked significantly more $(\mathrm{p}=0.012)$ and tended to be rooting more $(\mathrm{p}=0.098)$ than indoor pigs. Amino acid level did not affect the activity behaviour and social interactions of the pigs. Indoor pigs given diets R-7 and R-14 were drinking significantly more often than indoor pigs receiving the $\mathrm{R}$ diet, but had less contact with other pigs ( $\mathrm{p}=0.020$ and $\mathrm{p}=0.002$, respectively). For outdoor pigs no such effect of amino acid level was found. Queuing for feed decreased with increasing age of the pigs, both indoors and outdoors $(p=0.009)$. Rooting decreased and sleeping increased with the age of indoor pigs $(p=0.014$ and $\mathrm{p}=0.001$, respectively), whereas no consistent trend for outdoor pigs was found. Sniffing, nibbling, pushing ( $\mathrm{p}=0.001$ for all) and tail manipulation $(\mathrm{p}=0.002)$ occurred more often indoors than outdoors. The results show that pigs in an outdoor system are more active and perform more natural behaviours, such as foraging and rooting, than pigs in an indoor system. Furthermore, roughages, such as pasture, and large areas may play an important role in occupying pigs and therefore contribute to less aggressive behaviours.
\end{abstract}

Keywords: pig, social behaviour, housing, outdoor, feeding, amino acid

\section{Zusammenfassung}

Titel der Arbeit: Die Aktivität und das Sozialverhalten von Schweinen aus konventioneller Haltung und aus Freilandhaltung

Es wurden die Aktivität und das Sozialverhalten von Schweinen aus konventioneller Haltung und aus Freilandhaltung bei verschiedenen Aminosäuregehalten im Futter untersucht. Die Schweine erhielten in einer energiereduzierten Phasenfütterung entweder die empfohlene (R), eine um 7 \% (R-7) oder eine um 14 \% (R-14) verringerte Menge an Aminosäuren. 96 im Freiland geborene Schweine der Rassenkreuzung Hampshire $\times$ Schwedische Landrasse $\times$ Schwedische Yorkshire wurden paritätisch entweder konventionell im Stall oder in Freilandhaltung auf der Weide aufgezogen.

Freilandschweine bewegten sich signifikant mehr $(\mathrm{p}=0,012)$ und hatten eine Tendenz zum vermehrten Wühlen $(\mathrm{p}=0,098)$ als konventionell gehaltene Schweine. Der Aminosäuregehalt in Futter hat die Aktivität und das Sozialverhalten von Schweinen nicht beeinflusst. Konventionell gehaltene Schweine, die R-7 und R-14 erhielten, tranken signifikant mehr als konventionell gehaltene Schweine, die R erhielten, hatten jedoch weniger Kontakt mit anderen Schweinen ( $p=0,020$ und $p=0,002$, respektive). Für Freilandschweine hatte der Aminosäuregehalt im Futter jedoch keinen Einfluss auf die Aktivitäten „Trinken“ und „Kontakt". Mit steigendem Alter verringerten sich die Zeiten des „Schlangestehens für Futter" für die Schweine beider Haltungsarten. Bei konventionell gehaltenen Schweinen traten „Wühlen“ und „Schlafen“ vermehrt mit steigendem Alter auf ( $p=0,014$ und $\mathrm{p}=0,001$, respektive), während für Freilandschweine kein einheitlicher Trend sichtbar wurde. Aktivitäten des Sozialverhaltens wie „Schnüffeln“, „Knabbern“, „Stoßen“ ( $p=0,001$ für alle) und „Schwanzbeißen“ $(p=0,002)$ kamen häufiger in der konventionellen als in der Freilandhaltung vor.

Die Resultate zeigen, dass im Vergleich zu konventionell gehaltenen Schweinen die Freilandschweine, die Zugang zur größeren Flächen hatten, aktiver waren und ein natürlicheres Verhalten wie „Grasen“" und „Wühlen“ zeigten. Des Weiteren weisen die Resultate darauf hin, dass Raufutter wie z. B. Weide, eine bedeutende Rolle spielt, um die Schweine zu beschäftigen und aggressives Verhalten zu mindern. 


\section{Introduction}

One important component in organic production is to maintain the natural behaviour repertoire of the animal. All aspects of animal productivity are related to the animals' behaviour (MCGLONE, 1991). The environment has great influence on the wellbeing and the behaviour of pigs and foraging behaviour, such as rooting and grazing, is closely linked to exploratory behaviours. Pigs perform these behaviours not only to gain feed, but also to assess the potential of different areas (WOOD-GUSH et al., 1990; SHNEIDER and WALTER, 1996; MICKLICH and MATTHES, 1999). An increased level of activity behaviour may be motivated by the pigs' nutrient requirements and may be represented by appetite foraging behaviour. Foraging behaviour can relate to growing animals' higher protein requirement. It has been suggested that rooting behaviour in straw material is induced by an inadequate content of crude protein (JENSEN et al., 1993) and that a restricted feed allowance can result in more active behaviours (GRAVES et al., 1978; SHNEIDER and WALTER, 1996; SPITSCHAK, 1997; MICKLICH and MATTHES, 1999; STERN and ANDRESEN, 2003).

Regulations related to the formulation of organic pig diets limit the number of possible and approved feedstuffs that are rich in protein and have a desirable amino acid profile. To compensate for the deficiencies in essential amino acids, a high inclusion level of protein in the diet is therefore necessary, resulting in a surplus of protein. This can affect production results negatively and increase the losses of nitrogen to the environment. Part of this problem could be overcome by using a phase feeding strategy to growing/finishing pigs, because this allows a supply of protein and amino acids that better reflects the need during the growth period (NONN and FRANKE, 1998; NONN and JEROCH, 2000). Further, a sufficient total daily intake of protein and amino acids could probably be assured by using ad libitum feeding. However, the diet should have a lower energy density than used conventionally in order not to compromise the carcass quality (MICKLICH et al., 1999; HEYER et al., 2005). In the present experiment pigs received recommended (R), $7 \%$ lower (R-7) or $14 \%$ lower (R-14) levels of amino acids, in a phase feeding system with a low-energy diet provided ad libitum. The results from this study on performance, carcass quality and health have been published elsewhere (НØØK PRESTO et al., 2007). Roughages are of importance to induce satiety and to maintain a normal behaviour repertoire and by keeping the pigs outdoors, on pasture, these demands can be fulfilled. By increasing the time spent eating; roughages can keep the pigs occupied and reduce stress and aggression. Several studies have shown that aggressive and harmful behaviours were reduced in roughage or straw enriched environments (SAMBRAUS, 1991; PETERSEN et al., 1995; SAMBRAUS, 1997; BEATTIE et al., 2000; PERSSON et al., 2004).

Based on these dietary and behavioural issues in organic production, the aim of this project was to investigate, whether activity behaviour and social interactions of pigs at different ages are affected by different dietary levels of amino acids in indoor and outdoor systems. 


\section{Material and methods}

\section{Animals}

This study comprised 96 growing/finishing pigs born outdoors of Swedish Landrace $\times$ Swedish Yorkshire sows, inseminated by semen from Hampshire boars. Sows farrowed in huts in individual paddocks and when the piglets were four days old they were weighed, castrated, and individually marked in the ears. The piglets did not get an iron injection and their teeth were not clipped. After two weeks the sows and the piglets were moved to nursing paddocks, where three or four sows were housed together. The nursing paddocks contained a hut and a shed with straw. The piglets did not get any creep feed. Weaning of piglets occurred at an average age of 47 days (SD 0.7 days) and they were then moved to either a pen indoors or a pasture outdoors. In each pen or pasture eight pigs were housed, four females and four castrates.

\section{Housing and pastures}

The indoor pens consisted of a concrete floor with a slatted floor in the dunging area with free access to straw. The total area was $14.8 \mathrm{~m}^{2}$, giving a floor area of $1.1 \mathrm{~m}^{2}$ per pig. The divisions between the pens were metal bars at the dunging area and solid walls in the rest of the pen. One feeder with one feeding space was placed in the front of each pen and four water nipples were placed over the slatted floor. The outdoor pastures had a single electric fence $30 \mathrm{~cm}$ above the ground and the total area was not less than 0.3 ha $\left(375 \mathrm{~m}^{2}\right.$ per pig). To prevent the pigs escaping, they were kept in a smaller part of the pasture directly after weaning. This was surrounded by a wooden and wire mesh fence together with an electric fence and had an area of approximately $400 \mathrm{~m}^{2}\left(50 \mathrm{~m}^{2}\right.$ per pig). When the pigs had acclimatised to the new groups and the environment, they were allowed access to the whole area of pasture. The pastures did not contain any crops, only weeds and grasses. In the centre of the smaller part of the pasture, the pigs had access to a shade $\left(1 \mathrm{~m}^{2}\right.$ per pig) with straw bedding. One feeder was placed in the front of every pasture with a water nipple close by. Only one pig could eat from the feeder at the same time. Each pasture was also supplied with a water sprinkler to create a mud wallow.

\section{Feeding and recording}

At weaning piglets within litter were randomly allocated to three treatments according to sex and live weight. Pigs in treatment $\mathrm{R}$ received a diet with an amino acid level (lysine, methionine + cystine and threonine) in accordance with the current recommendation for growing/finishing pigs in Sweden (SIMONSSON, 1994). Pigs in treatment R-7 and R-14 were given diets containing $7 \%$ and $14 \%$ lower amino acid levels, respectively, than the recommendation (Table 1).

Table 1

Digestible amino acid level (g/MJ ME) in the different treatments and phases

(Aminosäuregehalt im Futter der unterschiedlichen Versuchseinheiten)

\begin{tabular}{lcccc}
\hline Treatment & Phase & Lysine & Methionine + Cystine & Threonine \\
\hline R & 1 & 0.70 & 0.43 & 0.46 \\
& 2 & 0.50 & 0.31 & 0.33 \\
R-7 & 1 & 0.65 & 0.40 & 0.43 \\
& 2 & 0.46 & 0.29 & 0.31 \\
R-14 & 1 & 0.60 & 0.37 & 0.39 \\
& 2 & 0.43 & 0.27 & 0.28 \\
\hline
\end{tabular}


The amino acid supply (g digestible/MJ ME) was based on a 2-phase system, with a high concentration from weaning to $60 \mathrm{~kg}$ live weight (phase 1) and a lower concentration from $60 \mathrm{~kg}$ live weight to slaughter (phase 2), and all diets were provided ad libitum, see НØØK PRESTO et al., 2007. The experiment started at an average live weight of $19.1 \mathrm{~kg}$ (SD $3.5 \mathrm{~kg}$ ). In total there were 6 pens indoors and 6 pastures outdoors, i.e. two replicates per treatment (Figure 1). The pigs were weighed at the start of the experiment and thereafter every third week. Before the change from the phase 1 diet to the phase 2 diet, and before slaughter, the pigs were weighed every week. The pigs were slaughtered at an average live weight of $116.3 \mathrm{~kg}$ (SD $7.8 \mathrm{~kg})$.

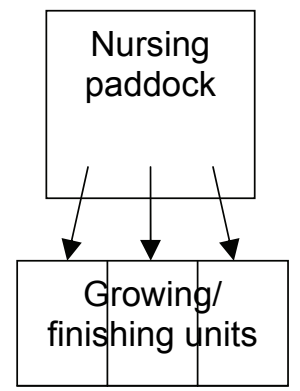

$\begin{array}{lll}R & \text { R-7 } & \text { R-14 }\end{array}$ Indoor

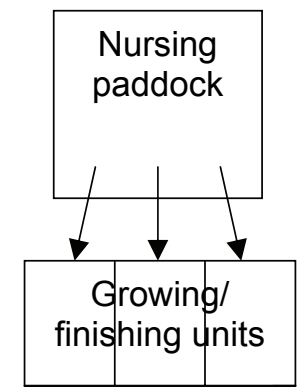

$\begin{array}{lll}R & R-7 & R-14\end{array}$

Outdoor

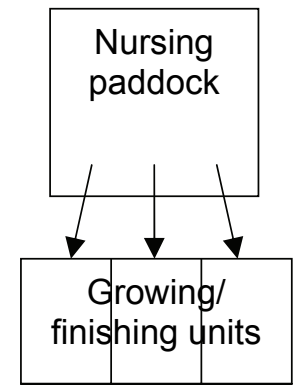

$\begin{array}{lll}R & \text { R-7 } & \text { R-14 }\end{array}$ Indoor

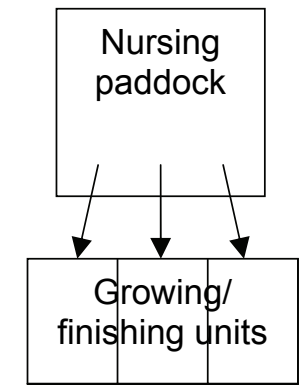

$\begin{array}{lll}\mathrm{R} & \mathrm{R}-7 & \mathrm{R}-14\end{array}$

Outdoor

Fig. 1: Allocation of piglets from nursing paddocks into the different treatments (R, R-7, R-14)

(Aufteilung der Ferkel in den Weideparzellen nach den unterschiedlichen Aminosäuregaben [R, R-7, R-14])

\section{Behaviour studies}

Activity behaviour and social interactions of the pigs were studied on three occasions per group at a mean age of 60,110 and 140 days. The observations were recorded by one observer, who was standing outside the pen or the pasture and the observation did not start until the pigs had been accustomed and paid no attention to the observer. All observations were performed between 8 a.m. and 12 a.m. Six rounds per group were made in a certain order to distribute the observations of the groups equally over time, and each group was studied for an eleven minute session per round. The observations consisted of two kinds of sampling and recording; instantaneous scan sampling for activity behaviours, and frequencies of social interactions. Every session comprised instantaneous scan sampling during the first minute, between minute five and six and finally between minute ten and eleven and was directed at identifying what activity behaviours the pigs were doing. Between the scan sampling observations, frequencies of social interactions were registered for a total of $8 \mathrm{~min}(2 \times 4 \mathrm{~min})$. A time-schedule of the observations during a session is presented in Figure 2.

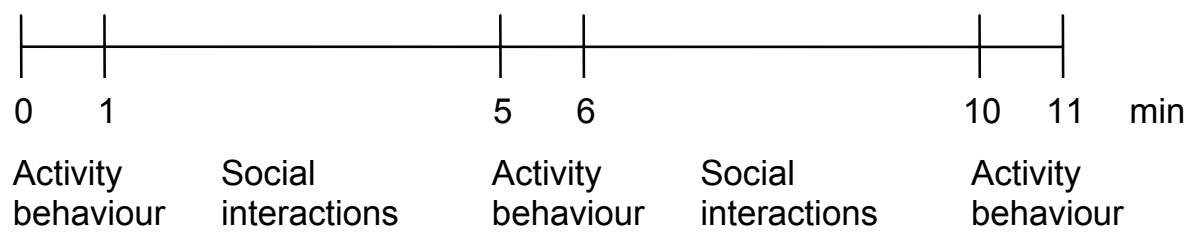

Fig. 2: Time-schedule of a session (Zeitplan der Verhaltensbeobachtungen)

The definitions of all behaviour parameters in the scan sampling and social interaction observations are presented in Tables 2 and 3, respectively. As it sometimes was difficult to distinguish what the pigs were doing, especially outdoors, some of the 
parameters were combined in the analysis. For scan sampling, resting was combined with sleeping, foraging with rooting and biting bars/fences (also biting at feeder) with other. Standing/walking and running were combined and named walking. If a pig was rooting or drinking while sitting, rooting or drinking were given priority, and registered as the main activity. Social interactions were registered as frequencies. A new frequency was counted when new pigs were interacting or if the interaction stopped for three seconds or more, and then started again. For social interactions, playfighting and neighbour were combined with other-social in the analysis.

Table 2

Definitions of behaviour parameters of the scan sampling

(Definitionen der erfassten Verhaltensparameter)

\begin{tabular}{ll}
\hline Behaviour parameters & Definition (indoor/outdoor) \\
\hline Eating & A pig has its head inside the feeder \\
Queuing & A pig is waiting beside the feeder for its turn \\
Sleeping & A pig is laying down with eyes closed \\
Resting & A pig is laying down with eyes open \\
Sitting & A pig is sitting up on front legs \\
Standing/walking & A pig is standing or walking \\
Running & A pig is running \\
Rooting & A pig is rooting or trying to root on the floor/in the mud or in the deep straw \\
Foraging & A pig is eating straw/straw or grass \\
Drinking & A pig has a water nipple in its mouth \\
Contact & A pig is touching another pig in some way \\
Biting the bars/fences & A pig has a bar/board in its mouth \\
Other & A pig does none of the above activities (e.g. rubbing itself/mud bathing) \\
\hline
\end{tabular}

Table 3

Definitions of behaviour parameters of social interaction observations

(Definitionen der erfassten Verhaltensparameter)

\begin{tabular}{ll}
\hline Behaviour parameters & Definition \\
\hline Sniffing & A pig is sniffing at another pig \\
Nosing & Two pigs have nose to nose contact \\
Nibbling & A pig nibbles (almost bites) another pig \\
Playing & One or several pigs play (jump, carry straw or run) \\
Riding & A pig is mounting another pig \\
Aggression & Two or more pigs are fighting* \\
Pushing & A pig pushes or lifts another pig that lies down \\
Tail manipulation & A pig is biting or touching another pig's tail with its snout \\
Ear manipulation & A pig is biting or touching another pig's ear with its snout \\
Crowding & Two or more pigs are crowding/pushing each other without aggression** (no sound) \\
Neighbour & A pig is in contact with a pig in a neighbouring pen \\
Play-fighting & Two or more pigs are play-fighting \\
Other-social & Other social behaviours \\
\hline
\end{tabular}

* recorded as aggression - by feeder, by water nipple, at another place in pen/pasture

** recorded as crowding - by feeder, by water nipple.

\section{Statistical analysis}

Activity behaviour measured number of pigs per pen/pasture performing a certain activity in each session (3 scan samplings per session) and social interaction parameters measured frequency of each behaviour performed per pen/pasture in each session ( $8 \mathrm{~min}$ per session). All registrations were added together per pen/pasture and occasion. Activity behaviour was analysed as the average total number of pigs per scan sampling (18 scan samplings per occasion) and presented as percentage of pigs per pen/pasture and occasion. Social interactions were analysed and presented as the total 
frequency of each behaviour performed per pen/pasture and occasion (48 min per occasion). These parameters were evaluated with procedure Mixed in SAS (SAS Institute, Cary, NC, USA, version 9.1). The model included housing system (pen/pasture), amino acid level (R/R-7/R-14) and age of the pig (60, 110 or 140 days) as fixed effects. Group within housing system was the statistical unit and was treated as random. Two-way interactions between the fixed effects were included in the model, when significant $(\mathrm{p}<0.05)$. As the behaviour observations were performed repeatedly, age was analysed with repeated statement in procedure Mixed. The covariance structure was treated as Unstructured for the activity behaviour and as Spatial Power for the social interactions.

\section{Results}

\section{Activity behaviour}

The number of pigs walking differed significantly between the two housing systems; outdoor pigs walked more than indoor pigs (Figure 3). A tendency to a higher number of pigs rooting or trying to root was found for outdoor pigs compared to indoor pigs. Amino acid level did not influence the activity of the pigs (not tabled). Interaction between amino acid level and housing system was found for drinking $(\mathrm{p}=0.020)$ and contact ( $\mathrm{p}=0.002$ ). Indoor pigs given diets R-7 and R-14, were drinking significantly more often than those indoor pigs receiving the $\mathrm{R}$ diet ( 1.8 and 1.7 vs. $0.5 \%$ pigs per pen and occasion), but had less contact with other pigs (1.9 and 1.6 vs. $5.2 \%$ pigs per pen and occasion). For outdoor pigs, however, no effect of amino acid level on drinking and contact was found.

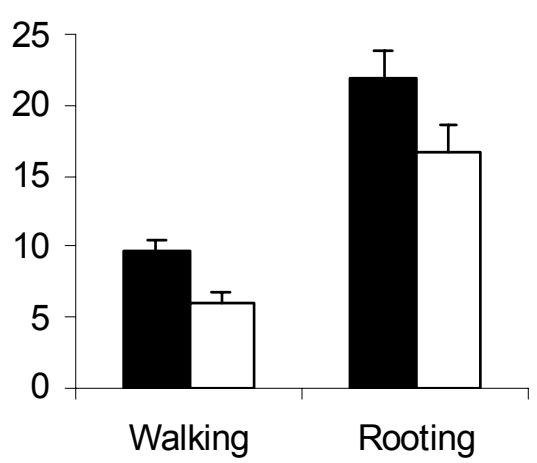

Fig. 3: Effect of housing system on walking and rooting behaviour for outdoor (black bars) and indoor (white bars) pigs. Least square means of percent pigs per pen/pasture (8 pigs) and occasion (18 scan samplings) performing each activity; $\mathrm{p}=0.012$ for walking and $\mathrm{p}=0.098$ for rooting, and pooled standard error (SE), $\mathrm{n}=36$ (Unterschied bei Bewegungs- und Wühlaktivitäten abhängig vom Haltungssystem)

The number of pigs queuing for feed and other activities was influenced by the age of the pigs, independent of housing system. Queuing decreased with increasing age of the pigs $(\mathrm{p}=0.009)$. Other activities were lower at the observation at 140 days than at the observations at 60 and 110 days ( $<<0.05$ for both). The parameters eating, rooting and sleeping showed interactions between housing system and age (Table 4). In both housing systems, more pigs were eating at the observation at 110 days compared with the observation at 60 days. At 140 days, eating decreased to the same level as at 60 days for indoor pigs, whereas for outdoor pigs no significant decrease was observed. For indoor pigs, rooting decreased and sleeping increased with increasing age, but did not show any consistent trend for outdoor pigs. 
Table 4

Interactions between housing system and age. Least square means of percent pigs per pen/pasture ${ }^{1}$ and occasion (18 scan samplings) performing each activity and pooled standard error (SE), $\mathrm{n}=36^{2}$

(Beziehungen zwischen Haltungssystem und Alter der Tiere)

\begin{tabular}{lcccccccc}
\hline \multirow{2}{*}{ Behaviour } & \multicolumn{3}{c}{ Indoor - age, days } & \multicolumn{3}{c}{ Outdoor - age, days } & \multirow{2}{*}{ SE } & p-value $^{3}$ \\
& 60 & 110 & 140 & 60 & 110 & 140 & & \\
\hline Eating & $10.2^{\mathrm{a}}$ & $11.7^{\mathrm{b}}$ & $9.0^{\mathrm{a}}$ & $5.2^{\mathrm{a}}$ & $8.7^{\mathrm{b}}$ & $8.0^{\mathrm{b}}$ & 0.71 & 0.014 \\
Rooting & $24.8^{\mathrm{a}}$ & $15.7^{\mathrm{b}}$ & $9.4^{\mathrm{b}}$ & $21.9^{\mathrm{a}}$ & $13.3^{\mathrm{b}}$ & $30.6^{\mathrm{a}}$ & 2.45 & 0.014 \\
Sleeping & $44.1^{\mathrm{a}}$ & $55.8^{\mathrm{b}}$ & $70.4^{\mathrm{c}}$ & $56.7^{\mathrm{a}}$ & $60.0^{\mathrm{a}}$ & $43.9^{\mathrm{b}}$ & 3.59 & 0.001 \\
\hline
\end{tabular}

1) 8 pigs in each pen/pasture, ${ }^{2)} 12$ pens/pastures $\times 3$ occasions, ${ }^{3)}$ p-value for interaction term (housing system $\times$ age)

Means with different superscript $(\mathrm{ab})$ within row and housing system differ significantly $(\mathrm{p}<0.05)$.

\section{Social interactions}

Higher frequency of behaviours such as sniffing, nibbling, pushing and tail manipulation was observed in the indoor system than in the outdoor system (Figure 4).
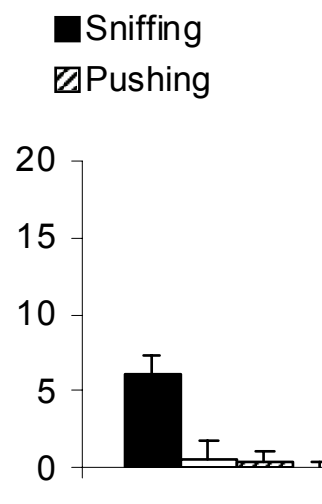

$\square$ Nibbling

mTail manipulation

Outdoor

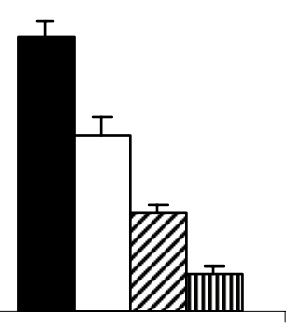

Indoor

Fig. 4: Effect of housing system on the pigs' social interactions. Least square means of the frequency of each social behaviour performed per pen/pasture ( 8 pigs) and occasion ( $48 \mathrm{~min}) ; \mathrm{p}=0.001$ for sniffing, nibbling and pushing, respectively and $\mathrm{p}=0.003$ for tail manipulation, and pooled standard error (SE), $\mathrm{n}=36$

(Sozialverhalten abhängig vom Haltungssystem)

Amino acid level did not affect social interactions between the pigs (not tabled). An effect of age was found for nibbling, both indoors and outdoors, which was less frequently performed at 60 days compared to 110 and 140 days (Table 5). Playing decreased from 60 to 110 days, but thereafter no significant age effect was observed. The frequency of aggression-feed, crowding-feed and crowding-water was significantly lower at the age of 140 days than at 60 and 110 days. Pushing decreased with increasing age, but was only significant between 60 and 140 days.

\section{Table 5}

Effect of age on the pigs' social interactions. Least square means of the frequency of each social behaviour performed per pen/pasture ${ }^{1}$ and occasion (48 $\mathrm{min}$ ) and pooled standard error (SE), $\mathrm{n}=36^{2}$

(Sozialverhalten abhängig vom Alter)

\begin{tabular}{|c|c|c|c|c|c|}
\hline \multirow{2}{*}{ Behaviour } & \multicolumn{3}{|c|}{ Age, days } & \multirow{2}{*}{$\mathrm{SE}$} & \multirow{2}{*}{ p-value } \\
\hline & 60 & 110 & 140 & & \\
\hline Nibbling & $3.33^{\mathrm{a}}$ & $7.42^{b}$ & $7.25^{\mathrm{b}}$ & 1.304 & 0.012 \\
\hline Playing & $3.33^{\mathrm{a}}$ & $0.83^{\mathrm{b}}$ & $0.50^{\mathrm{b}}$ & 0.702 & 0.015 \\
\hline Aggression-feed & $17.58^{\mathrm{a}}$ & $13.83^{\mathrm{a}}$ & $7.58^{\mathrm{b}}$ & 1.576 & 0.001 \\
\hline Pushing & $4.67^{\mathrm{a}}$ & $3.83^{\mathrm{ab}}$ & $1.75^{\mathrm{b}}$ & 0.745 & 0.030 \\
\hline Crowding-feed & $12.08^{\mathrm{a}}$ & $8.42^{\mathrm{a}}$ & $3.42^{\mathrm{b}}$ & 1.885 & 0.008 \\
\hline Crowding-water & $0.92^{\mathrm{a}}$ & $1.33^{\mathrm{a}}$ & $0.00^{\mathrm{b}}$ & 0.229 & 0.001 \\
\hline
\end{tabular}

1) 8 pigs in each pen/pasture, ${ }^{2)} 12$ pens/pastures $\times 3$ occasions

Means with different superscript $(a b)$ within row differ significantly $(\mathrm{p}<0.05)$. 
Interactions between housing system and age of the pigs were found for nosing, riding, aggression-pen/pasture, ear manipulation and other-social behaviours (Table 6). Nosing was constant for indoor pigs, but increased outdoors with increasing age. Riding, aggression-pen/pasture, ear manipulation and other-social decreased with increasing age for indoor pigs, but were unaffected for outdoor pigs where those parameters in general were performed less frequently. Sniffing, aggression-water and tail manipulation were not affected by age irrespective of housing system (not tabled).

Table 6

Interactions between housing system and age. Least square means of the number of the frequency of each social behaviour performed per pen/pasture ${ }^{1}$ and occasion (48 $\mathrm{min}$ ) and pooled standard error (SE), $\mathrm{n}=36^{2}$ (Beziehungen zwischen Haltungssystem, Soziaalverhalten und Alter der Tiere)

\begin{tabular}{lcccccccc}
\hline \multirow{2}{*}{ Behaviour } & \multicolumn{3}{c}{ Indoor - age, days } & \multicolumn{3}{c}{ Outdoor-age, days } & \multirow{2}{*}{ SE } & p-values $^{3}$ \\
\hline Nosing & 60 & 110 & 140 & 60 & 110 & 140 & $0^{\mathrm{a}}$ & \\
Riding & 4.00 & 3.17 & 1.67 & $0.83^{\mathrm{a}}$ & $3.00^{\mathrm{a}}$ & $7.83^{\mathrm{b}}$ & 0.977 & 0.001 \\
Aggression- & $8.00^{\mathrm{a}}$ & $0.17^{\mathrm{b}}$ & $0.00^{\mathrm{b}}$ & 0.67 & 0.17 & 0.00 & 1.068 & 0.002 \\
pen/pasture & $17.00^{\mathrm{a}}$ & $8.50^{\mathrm{b}}$ & $3.50^{\mathrm{c}}$ & 5.50 & 8.50 & 9.83 & 1.567 & 0.001 \\
Ear manipulation & $11.67^{\mathrm{a}}$ & $4.33^{\mathrm{b}}$ & $2.00^{\mathrm{b}}$ & 0.17 & 0.50 & 0.00 & 1.513 & 0.008 \\
Other-social & $4.67^{\mathrm{a}}$ & $2.50^{\mathrm{b}}$ & $0.50^{\mathrm{c}}$ & 0.33 & 0.17 & 0.00 & 0.524 & 0.006 \\
\hline
\end{tabular}

1) 8 pigs in each pen/pasture, ${ }^{2)} 12$ pens/pastures $\times 3$ occasions, ${ }^{3)}$ p-value for interaction term (housing system $\times$ age)

Means with different superscript $(\mathrm{abc})$ within row and housing system differ significantly $(\mathrm{p}<0.05)$.

\section{Discussion}

Walking and rooting (or trying to root) occurred more often by outdoor than by indoor pigs in the present study. The higher number of pigs walking could be due to the fact that the pigs in the outdoor system had to move between the pasture and the feeding and drinking space and the higher number of pigs rooting could be part of an explorative behaviour. In accordance with WOOD-GUSH et al. (1990), higher rooting activity was observed shortly after introduction to a semi-natural environment, than after three weeks, and the authors suggested that the initial rooting activity was mainly explorative. Moreover, STERN and ANDRESEN (2003) found that rooting and grazing were more frequently performed on new allotted areas. Indoor pigs in the present study were rooting more at 60 days than later, and it has been reported that young pigs spend more time manipulating and investigating the environment than older pigs (STOLBA and WOOD-GUSH, 1989). We did not find this pattern for outdoor pigs, probably because they had access to a large area which took a long time to explore, and at the end of the growing/finishing period the pigs had not yet finished exploring it. All pigs were born and raised outdoors until weaning when they were moved to new environments, either outdoors or indoors, and some of the differences in behaviour between the two housing systems in the present study could be explained by that. More rooting and feeding has also been found for outdoor pigs, which were bred outdoors, compared to outdoor pigs that were moved to outdoor areas first after weaning (WEBSTER and DAWKINS, 2000). The same pattern occurred for pigs weaned from outdoor systems, when mixed with indoor pigs (COX and COOPER, 2001). This gives support to the contention that pigs raised outdoors are more adept at finding feed than pigs raised indoors. Environmental changes at the start of the growing/finishing period were found to be negative for the pigs' growth rate (STERN et al., 2003) and this indicates that a change at weaning from outdoor areas to indoor pens might be a larger change for pigs than moving from one outdoor system to another. 
It was observed that the pigs tried to eat together, which often resulted in queuing for feed. This might be due to the fact that pigs are gregarious animals which like to eat simultaneously (GRAVES, 1984; ENGLISH et al., 1988). Overall, it seemed that the indoor pigs in the present study were eating more to occupy themselves, because there was no opportunity for them to root in soil or mud or graze. Queuing decreased as the pigs from both housing systems got older. Crowding-feed, i.e. interactions between pigs by the feeder, also was diminished with age and this could indicate that they became used to the fact that they could not eat simultaneously, or that their ranking order was established at that time. ENGLISH et al. (1988) stated that a pig of low rank may be able to adapt, e.g. if the feeding space at the ad libitum feeder is limited, the low ranking pig can eat at non-popular times. In the present study, more indoor pigs were sleeping and they were less active when they got older than outdoor pigs. BOLHUIS et al. (2005) found no effect of age for inactive behaviours, however they found that inactivity was affected by housing and they reported that around $55 \%$ (enriched environment) and $70 \%$ (barren environment) of the pigs were inactive at 112 and 133 days, which is comparable with 55.8 and $70.4 \%$ sleeping for indoor pigs at 110 and 140 days in the present study. It was noted that indoors, some pigs were also awake while others were sleeping, whereas outdoors, all eight pigs slept together for a couple of hours each day. The indoor pigs that were awake might have been of lower rank and possibly took the chance to eat while the more dominant pigs were sleeping. According to JENSEN (1993), this type of behaviour is common among pigs of low rank.

In the present study, sniffing was constant both indoors and outdoors as the pigs grew older. Nibbling occurred more frequently for all pigs at 110 and 140 than at 60 days. It was noted that nibbling often developed into biting, causing the receiving pig to get up from a lying position as a result of the pain. Contradictory to the present findings LYONS et al. (1995) have shown that pigs spent more time biting pen-mates at earlier ages than at the middle and the end of the experiment. Furthermore, it has been observed that sniffing behaviour decreases with increasing age of the pigs in either enriched or barren environments (PETERSEN et al., 1995). Nosing increased with increasing age for outdoor pigs in the present study and this behaviour occurred when pigs were rooting next to each other and came too close. Nosing often occurred just before aggression and it seemed like the pigs were defending "their" area, especially when they got older. Social tactile interactions such as nose-to-body and nose-to-nose have been described by JENSEN (1980) as involved in individual animal recognition. In general, a higher frequency of sniffing, nibbling, pushing and tail manipulation was observed in the indoor compared to the outdoor system in the present study, and this could partly be due to a smaller available and more barren indoor area. Consequently, indoor pigs had limited possibilities to perform natural behaviours such as rooting and foraging properly. Instead, the pigs may have searched for an object to manipulate, and indoor pen mates could have been an alternative for the restless pig to interact with. Behaviours directed at indoor pen mates have also been found to be more performed among pigs in barren environments in previous studies (LYONS et al., 1995; PETERSEN et al., 1995; HASKELL et al., 1996; BEATTIE et al., 2000) and enriched environments have great impact on diminishing these behaviours (SIMONSEN, 1995). In contrast, MORRISON et al. (2003) found an increase in social tactile interactions and agonistic behaviours in pigs in deep-litter systems, probably as a consequence of 
increased locomotory and activity behaviours among those pigs. Straw and roughages are of importance to induce satiety and to maintain a normal behaviour repertoire. Pigs given straw were more active, performed more straw directed behaviour and had a lower incidence of oral behaviour directed at pen mates (MCKINNON et al., 1989). Outdoor pigs in the present study had access to pasture, whereas straw was given to the indoor pigs. In agreement with OLSEN et al. (2002) and PERSSON et al. (2004), we found that nibbling, pushing and tail manipulation occurred even less in the outdoor groups with access to pasture compared to the indoor groups receiving straw, during the whole observation period. It was also found that riding, aggressionpen/pasture, ear manipulation and other social parameters in general were performed less frequent outdoors than indoors. These types of social interactions can occur in response to a conflict and include offence, defence, submissive or escape components between individuals (PETHERICK and BLACKSHAW, 1987). Therefore they might be regarded as behaviours that are involved or lead to aggressive behaviours. The lower frequency of playing at 110 and 140 days compared to 60 days, in the present study, can be interpreted as a reduced interest for activity. This could be due to the fact that younger pigs are more active and are more curious and this is in agreement with previous findings (DOBAO et al., 1985; NEWBERRY and WOOD-GUSH, 1988; OLSEN et al., 2002).

Tail biting may develop as a consequence of stress or restlessness, and the present results showed a higher frequency of tail manipulation among the indoor pigs, which is in accordance with PETERSEN et al. (1995), who observed less tail biting in pigs reared in an enriched environment. Both tail-biting pigs and their victims have been shown to have a reduced welfare due to living in a stressful environment (SCHRØDER-PETERSEN and SIMONSEN, 2001). Outdoors, the pigs in the present study could increase the distance between each other and escape if necessary, instead of being forced to deal with another pig's attentions. In the groups on pasture, it was also observed less oral behaviour towards pen mates and comparable results were established in a previous study on pigs given roughages (OLSEN, 2001). WALLGREN and LINDAHL (1996) stated that tail biting influences the growth rate of pigs negatively.

No effect of amino acid level on activity behaviour and social interactions of the pigs were found in the present study. We originally assumed that ad libitum feeding could make it possible for the pigs to compensate low amino acid level and low energy content with high feed intake. However, feed consumption $(\mathrm{kg})$ did not differ between pigs fed different levels of amino acid, nor did growth rate, feed conversion ratio or lean meat content (HØØK PRESTO et al., 2007). These results indicate that ad libitum feeding provides the pigs' nutrient requirement even in diets with low amino acid level. Therefore it seems reasonable that no effect of amino acid levels on activity behaviour and social interactions were obtained. ANDRESEN and REDBO (1999), who studied the effect of crude protein level in the diet, did not find any affect on rooting activity. In contrast, JENSEN et al. (1993) observed that rooting behaviour in straw material was induced by inadequate crude protein content in the diet to indoor pigs. Rooting was also performed more frequently by outdoor pigs fed only $80 \%$ of the recommended feed allowance for pigs kept indoors, than at $100 \%$ feed allowance (STERN and ANDRESEN, 2003). 


\section{Results}

An outdoor system seems to allow pigs to be more active and perform more natural behaviours, such as foraging and rooting, than an indoor system. The lower frequency of aggressive behaviours among outdoor pigs demonstrates that roughage, such as pasture, and a larger area may play an important role in occupying the pigs. In the present study, amino acid level did not affect activity and social behaviours. This was probably because ad libitum feeding was applied and the pig's amino acid requirement was fulfilled even with diets containing 7 and $14 \%$ lower amino acid levels than recommended.

\section{Acknowledgments}

This study was supported by Formas (Swedish Research Council for Environment, Agricultural Sciences and Spatial Planning). The authors would like to thank the staff at Funbo-Lövsta research station (SLU) for taking excellent care of the pigs.

\section{References \\ ANDRESEN, N.; REDBO, I.: \\ Foraging behaviour of growing pigs on grassland in relation to stocking rate and feed crude protein level. Appl. Anim. Beh. Sci. 62 (1999), 183-197 \\ BEATTIE, V.E.; O'CONNELL, N.E.; MOSS, B.W.: Influence of environmental enrichment on the behaviour, performance and meat quality of domestic} pigs. Livest. Prod. Sci. 65 (2000), 71-79

BOLHUIS, J.E.; SCHOUTEN, W.G.P.; SCHRAMA, J.W.; WIEGANT, V.M.:

Behavioural development of pigs with different coping characteristics in barren and substrate-enriched housing conditions. Appl. Anim. Beh. Sci. 93 (2005), 213-228

COX, L.N.; COOPER, J.J.:

Observations on the pre- and post-weaning behaviour of piglets reared in commercial indoor and outdoor environments. Anim. Sci. 72 (2001), 75-86

DOBAO, M.T.; RODRIGAÑEZ, J.; SILIO, L.:

Choise of companions in social play in piglets. Appl. Anim. Beh. Sci. 13 (1985), 259-266

ENGLISH, P.R.; FOWLER, V.R.; BAXTER, S.; SMITH, B.:

Behaviour and welfare, in: The growing and finishing pig: improving efficiency. Farming Press, Ipswich, UK (1988), 101-111

GRAVES, H.B.

Behavior and ecology of wild and feral swine (Sus scrofa). J. Anim. Sci. 58 (1984), 482-492

GRAVES, H.B.; GRAVES, K.L.; SHERRITT, G.W.:

Social behaviour and growth of pigs following mixing during the growing-finishing period. Appl. Anim. Ethol. 4 (1978), 169-180

HASKELL, M.; WEMELSFELDER, F.; MENDL, M.T.; CALVERT, S.; LAWRENCE, A.B.:

The effect of substrate-enriched and substrate-impoverished housing environments on the diversity of behaviour in pigs. Behaviour 133 (1996), 741-761

HEYER, A.; ANDERSSON, K.; LEUFVEN, S.; RYDHMER, L.; LUNDSTRÖM, K.:

The effects of breed cross on performance and meat quality of once-bred gilts in a seasonal outdoor rearing system. Arch. Tierz. 48 (2005), 359-371

HØØK PRESTO, M.; ANDERSSON, H. K.; WALLGREN, P.; LINDBERG, J. E.: Influence of dietary amino acid level on performance, carcass quality and health of organic pigs reared indoors and outdoors. Acta Agric. Scand. Section A. Anim. Sci. 57 (2007), 61-72

JENSEN, P.:

An ethogram of social interaction patterns in group-housed dry sows. Appl. Anim. Ethol. 6 (1980), 341350

JENSEN, P.:

Animal behaviour and its' causes. Published by LT, Falköping, Sweden 1993 [in Swedish]

JENSEN, M.B.; KYRIAZAKIS, I.; LAWRENCE, A.B.:

The activity and straw directed behaviour of pigs offered foods with different crude protein content. Appl. Anim. Beh. Sci. 37 (1993), 211-221 
LYONS, C.A.P.; BRUCE, J.M.; FOWLER, V.R.; ENGLISH, P.R.:

A comparison of productivity and welfare of growing pigs in four intensive systems. Livest. Prod. Sci. 43 (1995), 265-274

MCGLONE, J.J.:

Techniques for evaluation and quantification of pig reproductive, ingestive, and social behaviors. J. Anim. Sci. 69 (1991) 4146-4154

MCKINNON, A.J.; EDWARDS, S.A.; STEPHENS, D.B.; WALTERS, D.E.:

Behaviour of groups of weaner pigs in three different housing systems. Brit. Vet. J. 145 (1989), 367-372

MICKLICH, D.; MATTHES, H.D.:

Die Weidehaltung von Sauen verschiedener Rassen auf Flußauenstandorten. Arch. Tierz. 42 (1999), 161-173

MICKLICH, D.; MATTHES, H.D.; HARTUNG, M.; MÖHRING, H.:

Mast-Schlachtleistung und Fleischqualität verschiedener Schweinerassen bei Stall- und Freilandhaltung. Arch. Tierz. 45 (2002), 247-253

MORRISON, R.S.; HEMSWORTH, P.H.; CRONIN, G.M.; CAMPBELL, R.G.:

The social and feeding behaviour of growing pigs in deep-litter, large group housing systems. Appl. Anim. Beh. Sci. 82 (2003), 173-188

NEWBERRY, R.C.; WOOD-GUSH, D.G.M.:

Development of some behaviour patterns in piglets under semi natural conditions. Anim. Prod. 46 (1988), 103-109

NONN, H.; FRANKE, C.:

Zur N-reduzierten Fütterung von Mastschweinen bei Einsatz freier Aminosäuren. Arch. Tierz. 41 (1998), 473-488

NONN, H.; JEROCH, H.:

Zur N-reduzierten Fütterung von Mastschweinen bei Einsatz freier Aminosäuren. Arch. Tierz. 43 (2000), 179-191

OLSEN, A.W.:

Behaviour of growing pigs kept in pens with outdoor runs I. Effect of access to roughage and shelter on oral activities. Livest. Prod. Sci. 69 (2001), 255-264

OLSEN, A.W.; SIMONSEN, H.B.; DYBKJÆR, L.:

Effect of access to roughage and shelter on selected behavioural indicators of welfare in pigs housed in a complex environment. Anim. Welf. 11 (2002), 75-87

PERSSON, E.; ANDERSSON, K.; ANDERSSON, K.:

Roughage has a positive impact on pig behaviour. Research news about organic farming in Scandinavia 3 (2004), 8-9 [in Swedish]

PETERSEN, V.; SIMONSEN, H.B.; LAWSON, L.G.:

The effect of environmental stimulation on the development of behaviour in pigs. Appl. Anim. Beh. Sci. 45 (1995), 215-224

PETHERICK, C.J.; BLACKSHAW, J.K.:

A review of the factors influencing the aggressive and agonistic behaviour of the domestic pig. Austr. J. Exp. Agric. 27 (1987), 605-611

SAMBRAUS, H.H.:

Tierschutz, Naturwissenschaft und Ethologie. Arch. Tierz. 35 (1991), 181-192

SAMBRAUS, H.H.:

Tierverhalten - Anzeiger für eine artgerechte Tierhaltung. Arch. Tierz. 40 (1997) Sonderheft, 26-34

SCHNEIDER, P.; WALTER, J.:

Ethologische Untersuchungen von Mastschweinen auf Weiden. Arch. Tierz. 39 (1996), 299-307

SCHRØDER-PETERSEN, D.L.; SIMONSEN, H.B.:

Tail biting in pigs. Vet. J. 162 (2001), 196-210

SIMONSEN, H.B.:

Effect of early rearing environment and tail docking on later behaviour and production in fattening pigs. Acta Agric. Scand. Section A. Anim. Sci. 45 (1995), 139-144

SIMONSSON, A.:

Nutrient recommendations and feed tables for pigs. University of Agricultural Sciences Research

SPITSCHAK, K.: Information Centre. Husdjur, 75. SLU Info/Repro, Uppsala 1994 [in Swedish]

Fruchtbarkeits- und Aufzuchtleistungen von Sauen mit Ferkeln in der Freilandhaltung. Arch. Tierz. 40 (1997), 123-134

STERN, S.; ANDRESEN, N.:

Performance, site preferences, foraging and excretory behaviour in relation to feed allowance of growing pigs on pasture. Livest. Prod. Sci. 79 (2003), 257-265 
STERN, S.; HEYER, A.; ANDERSSON, H.K.; RYDHMER, L.; LUNDSTRÖM, K.:

Production results and technological meat quality for pigs in indoor and outdoor rearing systems. Acta Acta Agric. Scand. Section A. Anim. Sci. 53 (2003), 166-174

STOLBA, A.; WOOD-GUSH, D.G.M.:

The behaviour of pigs in a semi-natural environment. Anim. Prod. 48 (1989), 419-425

WALLGREN, P.; LINDAHL, E.:

The influence of tail biting on performance of fattening pigs. Acta Vet. Scand. 37 (1996), 453-460

WEBSTER, S.; DAWKINS, M.:

The post-weaning behaviour of indoor-bred and outdoor-bred pigs. Anim. Sci. 71 (2000), 265-271

WOOD-GUSH, D.G.M.; JENSEN, P.; ALGERS, B.:

Behaviour of pigs in a novel semi-natural environment. Biol. Beh. 15 (1990), 62-73

Received: 2007-03-19

Accepted: 2008-06-13

Corresponding author:

MAGDALENA HØØK PRESTO

Department of Animal Nutrition and Management

Swedish University of Agricultural Sciences (SLU)

P.O. Box 7024

75007 Uppsala

Sweden

email: magdalena.presto@huv.slu.se 